\title{
PENGARUH STRATEGI PRE-WRITE, ORGANIZE, WRITE, EDIT, REVISE DAN SHARE (POWERS) DALAM KEMAMPUAN MENULIS BAHASA INGGRIS SISWA KELAS IV SDIT BAITURRACHMAN
}

\author{
Asih Rosnaningsih ${ }^{1}$, Prismawinda Ane ${ }^{2}$, Alifa HAJ ${ }^{3}$ \\ Universitas Muhammadiyah Tangerang \\ J1. Perintis Kemerdekaan No. 33 Cikokol, Kota Tangerang, Banten \\ Email: asihrosna@gmail.com , enkaavida@gmail.com , fhaalifahasna@gmail.com
}

\begin{abstract}
Abstrak
Kemampuan menulis adalah keterampilan menuangkan pikiran, pendapat, gagasan, dan juga perasaan dalam bentuk tulisan sehingga orang yang membaca dapat memahami isi dan pesan dapat tersampaikan dengan baik. Kemampuan menulis merupakan suatu keterampilan berbahasa yang harus dikuasi siswa dengan baik. Tujuan penelitian ini adalah untuk mengetahui pengaruh penggunaan strategi POWERS terhadap kemampuan siswa dalam menulis Bahasa Inggris. Penelitian ini menggunakan pendekatan kuantitatif dengan metode Quasi-Experimental design. Instrumen yang digunakan dalam penelitian ini adalah tes kemampuan menulis dalam bentuk essay. Hasil menunjukkan bahwa: (1) hasil pretest t-hitung 1,723 < t-tabel 2,001atau $\mathrm{H}_{0}$ diterima yaitu terdapat perbedaan kemampuan menulis diantara kelas kontrol dan kelas eksperimen, (2) hasil posttest thitung 2,622 > t-tabel 2,001 atau $\mathrm{H}_{1}$ diterima yaitu terdapat perbedaan kemampuan menulis diantara kelas kontrol dan kelas eksperimen setelah menggunakan strategi POWERS. Berdasarkan hasil tersebut, dapat disimpulkan bahwa strategi POWERS dapat mempengaruhi kemampuan siswa menulis essay dalam Bahasa Inggris.
\end{abstract}

Kata Kunci: Startegi POWERS, Kemampuan Menulis, Pembelajaran Bahasa Inggris

\begin{abstract}
The ability to write is a skill to express thoughts, opinions, ideas, and feelings in writing so that people who read can understand the contents and messages can be conveyed properly. Writing ability is a language skill that students must master well. The purpose of this study was to determine the effect of using the POWERS strategy on students' ability to write English. This research uses a quantitative approach with a Quasi-Experimental design method. The instrument used in this study was an essay writing ability test. The results show that: (1) pretest results of $t$-test $1.723<t$-table of 2.001 or $\mathrm{HO}$ are accepted namely there are differences in writing ability between the control class and the experimental class, (2) posttest results of t-test 2,622> t-table of 2,001 or H1 are accepted that is, there are differences in writing skills between the control class and the experimental class after using the POWERS strategy. Based on these results, it can be concluded that the POWERS strategy can affect students' ability to write essays in English.
\end{abstract}

Keywords: POWERS Strategy, Writing Ability, English Learning

\section{PENDAHULUAN}

Dalam Kurikulum Tingkat Satuan Pendidikan (KTSP) Tahun 2006 disebutkan bahwa, Bahasa Inggris merupakan alat berkomunikasi secara lisan dan tulis. Berkomunikasi adalah memahami dan mengungkapkan informasi, pikiran, perasaan dan mengembangkan ilmu pengetahuan, teknologi dan budaya. Kemampuan berkomunikasi dalam pengertian yang utuh adalah kemampuan berwacana, yakni kemampuan memahami dan atau menghasilkan teks 
lisan atau tulisan yang direalisasikan dalam empat keterampilan berbahasa, yaitu mendengarkan, berbicara, membaca, dan menulis. Keempat keterampilan inilah yang digunakan untuk menanggapi atau menciptakan wacana dalam kehidupan bermasyarakat. Oleh karena itu mata pelajaran Bahasa Inggris diarahkan untuk mengembangkan keterampilan-keterampilan tersebut

Berdasarkan Permendiknas Nomor 22 Tahun 2006 tentang Standar Isi dan Permendiknas Nomor 23 Tahun 2006 tentang Standar Kompetensi Lulusan, Bahasa Inggris merupakan salah satu muatan lokal wajib bagi semua siswa Sekolah Dasar dari kelas I hingga kelas VI. Alokasi waktu yang disediakan adalah 2 jam pelajaran. Muatan lokal merupakan kegiatan kurikuler untuk mengembangkan kompetensi yang disesuaikan dengan ciri khas dan potensi daerah, termasuk keunggulan daerah yang materinya tidak dapat dikelompokkan ke dalam mata pelajaran yang ada. Substansi muatan lokal ditentukan oleh sekolah. Dari penjelasan di atas, dapat kita pahami bahwa sejak dulu mata pelajaran Bahasa Inggris bukanlah mata pelajaran wajib bagi anak Sekolah Dasar. Mata pelajaran Bahasa Inggris diposisikan sebagai muatan lokal. Kebijakan untuk memasukkan pelajaran Bahasa Inggris di Sekolah Dasar sesuai dengan kebijakan Departemen Pendidikan dan Kebudayaan Republik Indonesia (Depdikbud RI) No. 0487/1992, Bab VIII yang menyatakan bahwa Sekolah Dasar dapat menambahkan mata pelajaran dalam kurikulumnya, asalkan pelajaran itu tidak bertentangan dengan tujuan pendidikan nasional. Dalam hal ini, sekolah memiliki kewenangan untuk memasukkan mata pelajaran Bahasa Inggris berdasarkan pertimbangan dan kebutuhan situasi.

Menulis merupakan suatu kegiatan komunikasi berupa penyampaian pesan secara tertulis kepada pihak lain dengan menggunakan bahasa tulis sebagai alat atau medianya, Aktifitas menulis melibatkan beberapa unsur, yaitu; penulis sebagai penyampaian pesan, isi tulisan, saluran atau media, dan pembaca. Kemampuan menulis ini sangat penting dimiliki oleh siswa karena dengan menulis siswa dapat menuangkan gagasan dalam bentuk bahasa tulis dalam tujuan, misalnya memberi tahu, meyakinkan, atau menghibur. Hasil dari proses kreatif ini biasa disebut dengan istilah karangan atau tulisan. Kedua istilah tersebut mengacu pada hasil yang sama meskipun ada pendapat yang mengatakan kedua istilah tersebut memiliki pengertian yang berbeda. Istilah menulis sering melekat pada proses kreatif yang 
sejenis ilmiah sementara istilah mengarang sering dilekatkan pada proses kreatif yang berjenis non ilmiah.

Namun realitanya kemampuan siswa dalam menulis Bahasa Inggris masih terbilang kurang menguasai dalam pembentukan kalimat, beberapa siswa juga mengalami kesulitan dan kekeliruan. Namun tak sedikit juga yang sudah mampu menulis Bahasa Inggris akan tetapi siswa yang mengalami kesulitan juga cukup banyak. Berdasarkan observasi awal pada siswa kelas IV SDIT Baiturrachman ditemukan beberapa masalah yaitu kurangnya penerapan strategi belajar yang tepat dalam pembelajaran menulis bahasa Inggris yang diterapkan oleh guru. Hal ini dilihat dari siswa yang kesulitan dalam menulis essay. Penerapan metode dan juga bahan ajar yang kurang relevan pada kegiatan pembelajaran. Kesulitan menentukan ide pokok yang akan dikembangkan. Kurangnya penguasaan kosa kata dan pengetahuan siswa tentang ejaan kosa kata bahasa Inggris yang benar. Siswa yang belum terbiasa menuangkan perasaan dan juga pemikirannya dalam bentuk tulisan.

Dalam penjelasan di atas dapat dikatakan bahwa kemampuan menulis siswa dalam Bahasa Inggris masih terbilang kurang dan untuk meningkatkan kemampuan menulis siswa dalam Bahasa Inggris perlu adanya evaluasi dan juga dianjurkan penggunaan strategi belajar yang baru serta penggunaan teknik dan media pembelajaran oleh guru. Dengan begitu maka diharapkan terjadinya perubahan demi meningkatkan kemampuan menulis siswa dalam Bahasa Inggris sesuai dengan Kompetensi Inti (KI) dan Standar Kompetensi Lulusan (SKL).

Tujuan penelitian adalah rumusan kalimat yang menunjukkan adanya suatu hal yang diperoleh setelah penelitian selesai. Sesuai dengan permasalahan yang dikemukakan di atas maka penelitian ini bertujuan untuk mengetahui pengaruh strategi POWERS dalam kemampuan menulis siswa kelas SDIT Baiturrachman Kunciran Tangerang. Manfaat dari penelitian ini adalah dapat dijadikan pedoman dalam praktik keterampilan sesuai dengan kurikulum 2013.

\section{TINJAUAN TEORITIS}

\section{Strategi Pembelajaran Pre-Write, Organize, Write, Edit, Revise dan Share (POWERS)}

Young (1998) menjabarkan bahwa POWERS adalah sebuah strategi yang sangat berguna untuk mengarahkan siswa pemula dalam proses menulis yang terdiri dari enam tahapan antara lain: Pre-Write, Organize, Write, Edit, Revise dan Share (Ratminingsih, 2019). 
Pertama yaitu fase Pre-Write siswa mempersiapkan diri terlebih dahulu sebelum memulai kegiatan menulis; guru memberi pengetahuan awal atau brainstorming agar siswa terhubung dengan materi yang akan diajarkan. Kedua yaitu fase Organize dimana siswa membuat list atau mengorganisasikan informasi apa saja yang akan dikembangkan dalam tulisannya. Selanjutnya fase ketiga yaitu Write, siswa menulis karangan sesuai dengan topik yang telah ditentukan dalam fase sebelumnya. Dalam fase keempat yaitu Edit, siswa mencoba untuk mengecek kembali isi atau konten dan juga dalam segi tata bahasa dan mekanis seperti tanda baca dan sebagainya. Kelima yaitu fase Revise dimana siswa membaca kembali hasil karangan dan memperbaiki (Self-corrected) kesalahan-kesalahan yang ditemukan dalam karangan tersebut. Terakhir yaitu fase Share dimana siswa membagikan hasil karangan yang dibuatnya Bersama teman sekelasnya. Dengan adanya fase Share ini akan membantu siswa dalam menemukan kelebihan dan kekurangan dalam karangan sehingga siwa mampu memaksimalkan hasil akhir dari tulisannya tersebut.

Adapun prosedur pelaksanaan strategi POWERS adalah sebagai berikut:

1) Guru memperlihatkan gambar (contoh: bedroom) dan memberikan kesempatan pada siswa untuk memberikan ranggapannya pada topic sebelumnya dengan menanyakan pertanyaan seperti "What picture is it?", "is there this picture?" dan lain lain.

2) Guru membagi siswa menjadi beberapa kelompok dengan rerdiri atas 6 orang dalam satu kelompok.

3) Guru memberikan mereka contoh teks dan menjelaskan paragraf deskriptif sebagai contoh.

4) Guru memotivasi siswa dalam diskusi kelompok untuk mencari ide yang ingin mereka tulis.

5) Guru meminta siswa membuat draft tulisannya.

6) Guru membimbing siswa mengembangkan dan menyusun draft menjadi sebuah paragraf.

7) Guru meminta siswa untuk menukarkan pekerjaan dengan reman lainnya dan memeriksa pekerjaan temannya.

8) Guru meminta siswa untuk merevisi dan menulis ulang tulisan mereka.

9) Guru meminta beberapa siswa untuk membaca tulisan mereka di depan kelas.

10) Guru meminta siswa mengumpulkan tulisan mereka.(Ratminingsih, 2019) 
Berdasarkan ke sepuluh langkah pembelajaran dengan menggunakan POWERS di atas dapat disimpulkan bahwa strategi ini sangatlah efektif karena disajikan dengan runtut dan sistematis. Dimulai dari persiapan menulis dan kegiatan yang berlangsung membuat siswa menjadi lebih terarah dalam belajar menulis essay. Siswa dibimbing secara perlahan sehingga siswa mampu membuat draft tulisannya sendiri.

Strategi POWERS adalah salah satu strategi dalam keterampilan menulis yang dapat meningkatkan kemampuan menulis siswa. Menurut Englert et al (1992), POWERS dapat digunakan sebagai strategi mnemonik dan menulis untuk membantu siswa mengingat langkah-langkah utama dari proses penulisan. Sebagai strategi, POWERS dapat diterapkan secara umum ke genre apapun. Sedangkan Graham dan Harris (2005: 3) menyatakan bahwa POWERS membantu penulis merevisi kalimat untuk kejelasan, niat, minat, dan kepercayaan. Selain itu, Fazio dan Gallagher (2009) mengatakan bahwa POWER dapat membimbing siswa melalui langkah-langkah penulisan eksposisi yang bermakna dari kegiatan inkuiri mereka (Yuliana, 2015).

\section{Kemampuan Menulis Bahasa Inggris}

Menulis merupakan suatu kegiatan komunikasi berupa penyampaian pesan secara tertulis kepada pihak lain dengan menggunakan bahasa tulis sebagai alat atau medianya, Aktifitas menulis melibatkan beberapa unsur, yaitu; penulis sebagai penyampaian pesan, isi tulisan, saluran atau media, dan pembaca. Sedangkan kemampuan menulis itu sendiri adalah keterampilan yang dimiliki siswa dalam mengolah Bahasa tulis yang mereka ciptakan. Pengertian kemampuan menulis menurut Rusyana (1984) adalah suatu kemampuan penulis dalam menggunakan pola-pola Bahasa tertentu dalam sebuah ragam tulisan untuk menginformasikan suatu ide atau pesan (Samsudin, 2012).

Menulis pada prakteknya memiliki beberapa tujuan. Rahmanto (2004) mengutarakan beberapa tujuan menulis, diantaranya: 1) Menjelaskan sesuatu kepada pembaca sehingga pembaca mengetahuinya, 2) Menyakinkan pembaca bahwa sesuatu itu begitu keadaannya sehingga pembaca paham dan meyakininya 3) Mempengaruhi pembaca dalam penerimaan atau penanggapan terhadap sesuatu hal. 4) Mengungkapkan pikiran dan perasaan dengan cara menjelaskan, meyakinkan, atau mempengaruhi orang lain (Sobari, 2012). 
Pada praktek pelaksanaannya, menulis sebagai sebuah proses memiliki beberapa tahapan. Suparno (2007) menjelaskan ada tiga tahapan utama dalam kegiatan menulis. Pertama yaitu tahap pra-menulis yaitu fase dimana penulis harus menentukan topik, maksud dan tujuan menulis, audiens, mengumpulkan infomasi pendukung dan membuat organisasi tulisan. Kedua yaitu tahap penulisan dimana siswa mengembangkan kerangka tulisan yang telah dipilih dan dianggap relevan dengan topik penulisan menjadi sebuah jarangan yang utuh. Ketiga yaitu tahap pasca-penulisan yaitu dimana penulis memperhalus dan menyempurnakan karangannya (revisi). Tahapan ini juga terdapat penyuntingan dan perbaikan baik dari segi isi maupun teknis (Sobari, 2012).

\section{METODE PENELITIAN}

Penelitian ini menggunakan pendekatan kuantitatif. Penelitian kuantitatif adalah pendekatan untuk menguji teori obyektif dengan memeriksa hubungan antar variabel. Variabel-variabel ini, pada gilirannya, dapat diukur, biasanya pada instrumen, sehingga data yang memiliki angka tersebut dapat dianalisis menggunakan prosedur statistik (Creswell, 2014).

Desain yang digunakan dalam penelitian ini adalah menggunakan jenis penelitian Quasi-Experiment. Penelitian dengan tipe ini bertujuan untuk mengukur dan membandingkan dua kelompok (kontrol dan eksperimen) dan melihat perbedaan dari hasil pretest dan posttest dari dua kelompok tersebut (Cohen, 2007). Kedua kelompok tersebut mengambil pretest dan posttest yang sama namun hanya kelompok eksperimen yang menerima perlakukan (treatment).

\section{Tabel 1. Desain Quasi-Experimental Research}

\begin{tabular}{|l|c|c|c|}
\hline \multicolumn{1}{|c|}{ Group } & Pretest & Perlakuan & Posttest \\
\hline Kontrol & $\mathrm{O}_{1}$ & - & $\mathrm{O}_{2}$ \\
\hline Eksperimen & $\mathrm{O}_{3}$ & $\mathrm{x}$ & $\mathrm{O}_{4}$ \\
\hline
\end{tabular}

Dalam penelitian ini terdapat dua kelompok yang digunakan sebagai sampel yaitu Semester IV-A sebagai kelas control (32 mahasiswa siswa) dan semester IV-B sebagai kelas eksperiment (32 mahasiswa). Jadi total sampel dalam penelitian ini berjumlah 64 mahasiswa. 
Instrumen dalam penelitian ini berupa tes essai dimana mahasiswa harus menuliskan pengalaman mereka pada saat melakukan liburan semester (Holiday). Prosedur penelitian ini yaitu mahasiswa mendapatkan pretest yaitu test menulis essai, kemudian kelas kontrol mendapatkan pembelajaran dengan metode ceramah biasa sedangkan kelas eksperiment diberi perlakuan Experiental Learning. Pada akhir fase kedua kelas mendapatkan posttest dengan soal yang sama. Materi pada saat pembelajaran yaitu membahas tentang teks deskriptif (descriptive text).

\section{HASIL PENELITIAN}

Penelitian ini akan menjawab dua hipotesis yaitu hipotesis pretest dan hipotesis posttest, yaitu sebagai berikut

\section{Hipotesis Pretest:}

$\mathrm{H} 0: \mu 1=\mu 2$

$\mathrm{H} 1: \mu 1 \neq \mu 2$

\section{Hipotesis Posttest:}

$\mathrm{H} 0: \mu 1=\mu 2$

$\mathrm{H} 1: \mu 1 \neq \mu 2$

Sebelum menjawab rumusan hipotesis pretest, maka peneliti akan terlebih dahulu menghitung statistika deskriptif dari data yang telah diperoleh dari kedua kelas yaitu kelas kontrol dan eksperimen seperti digambarkan pada table dibawah ini:

Tabel 2. Descriptive Statistic Pretest

\begin{tabular}{|l|c|c|c|}
\hline \multicolumn{1}{|c|}{ Group } & $\mathrm{N}$ & Mean & $\begin{array}{c}\text { Std. } \\
\text { Deviasi }\end{array}$ \\
\hline Kontrol & 30 & 69,67 & 7.063 \\
\hline Eskperimen & 30 & 72,17 & 6.390 \\
\hline
\end{tabular}

Dari Tabel 2 di atas diketahui bahwa terdapat dua kelompok yaitu kelompok kontrol dan kelompok eksperimen. Dari masing-masing kelompok memiliki sampel berjumlah 30 orang. Nilai rata-rata dari kelompok kontrol adalah 69,67 dan kelompok eksperimen dengan nilai rata-rata 72,17. Standar deviasi dari kelompok kontrol adalah 7.063 dan dari kelompok eksperimen adalah 6.390. Dapat disimpulkan nilai rata-rata dari kelompok eksperimen lebih besar dari pada nilai kelompok kontrol. 
Tabel 3. Hasil Uji Hipotesis Pretest

\begin{tabular}{|l|c|c|c|}
\hline \multicolumn{1}{|c|}{ Group } & t-hit. & t-tabel & Ket. \\
\hline $\begin{array}{l}\text { Kontrol } \\
\text { Eskperimen }\end{array}$ & 1,723 & 2,001 & Terima $\mathrm{H}_{0}$ \\
\hline
\end{tabular}

Untuk menjawab pertanyaan hipotesis pretest, maka peneliti menghitung dan menganalisis data hasil tes kemampuan menulis dengan menggunakan SPSS Versi 26.0 lalu didapatkan perhitungan yaitu t-hitung 1,723 < t-tabel 2,001 atau H1 ditolak dan H0 diterima. Dengan kata lain tidak terdapat perbedaan yang signifikan antara kelompok komtrol dan kelompok eksperimen pada kemampuan siswa dalam menulis bahasa Inggris.

Sedangkan pada data hasil posttest kemampuan menulis dapat diketahui data deskriptif dari kedua kelompok kontrol dan eksperimen yaitu sebagai berikut:

Tabel 4. Descriptive Statistic Posttest

\begin{tabular}{|l|c|c|c|}
\hline \multicolumn{1}{|c|}{ Group } & N & Mean & $\begin{array}{c}\text { Std. } \\
\text { Deviasi }\end{array}$ \\
\hline Kontrol & 30 & 74,33 & 6,915 \\
\hline Eskperimen & 30 & 79,00 & 6,873 \\
\hline
\end{tabular}

Dari Tabel 4 diatas diketahui bahwa terdapat dua kelompok yaitu kelompok kontrol dan kelompok eksperimen, yang masing-masing kelompok memiliki 30 orang sebagai sample. Nilai rata-rata yang diperoleh kelompok kontrol adalah 74,33 sedangkan pada kelompok eksperimen nilai rata-rata yang diperoleh adalah 79,00. Standar deviasi dari kelompok kontrol berjumlah 6,915 dan dari kelompok eksperimen berjumlah 6,873. Dapat disimpulkan bahwa nilai rata-rata dari kelompok eksperimen lebih besar dari kelompok kontrol.

Tabel 5. Hasil Uji Hipotesis Post-Test

\begin{tabular}{|l|c|c|c|}
\hline Group & t-hit. & t-tabel & Ket. \\
\hline $\begin{array}{l}\text { Kontrol } \\
\text { Eskperimen }\end{array}$ & 2,622 & 2,001 & Terima $\mathrm{H}_{1}$ \\
\hline
\end{tabular}

Untuk menjawab pertanyaan hipotesis pretest, maka peneliti menghitung dan menganalisis data hasil tes kemampuan menulis dengan menggunakan SPSS Versi 26.0 lalu didapatkan perhitungan yaitu t-hitung 2,622 > t-tabel 2,001 atau H1 diterima dan H0 ditolak. 
Dengan kata lain terdapat perbedaan yang signifikan pada kemampuan siswa dalam menulis bahasa Inggris setelah diberikan perlakuan strategi POWERS dalam kegiatan pembelajarannya.

Setelah melakukan proses pembelajaran dengan menggunakan strategi POWERS siswa menjadi lebih aktif saat proses pembelajaran berlangsung dan disaat guru menjelaskan materi yang diajarkan siswa lebih fokus dalam belajar. Karena, saat guru menjelaskan menggunakan teknik baru yang membuat siswa memiliki rasa ingin tahu dan juga karena menggunakan media pembelajaran yang sebelumnya belum dipakai.

Strategi ini nampaknya tepat untuk mengajarkan materi yang berkaitan dengan kemampuan menulis siswa dalam Bahasa Inggris. Dengan melatih kemampuan menulis siswa lebih sering dari biasanya maka siswa akan lebih mudah mengungkapkan suatu gagasan atau pemikiran dengan menggunakan penulisan kosa kata yang benar dalam Bahasa Inggris.

Strategi belajar ini dapat meningkatkan pemahaman siswa dalam menulis kosa kata dan kalimat dalam Bahasa Inggris karena siswa secara langsung melihat tulisannya dan mempraktikan setelahnya dengan melafalkan kosa kata yang dicontohkan oleh guru. Pada penelitian ini guru untuk mengajar dengan menggunakan strategi pembelajaran Pre-Write, Organize, Write, Edit, Revise dan Share (POWERS) dan menganalisis proses pembelajaran tersebut. Guru menjelaskan materi terlebih dahulu sesuai dengan langkah-langkah strategi POWERS. Setelahnya guru memberikan lembar tugas kepada siswa sebagai alat penilaian dari penggunaan strategi POWERS apakah sudah berhasil atau belum.

Setelah siswa mendengarkan dan paham akan penjelasan dari guru maka siswa selanjutnya mengerjakan lembar tugas yang berisi soal dari kosakata dengan materi number sebanyak 2 lembar yang berisi 10 butir soal perlembarnya. Di lembar pertama siswa diminta untuk mengisi huruf yang hilang dari kosakata dan di lembar kedua siswa diminta untuk merapihkan kosakata yang hurufnya tidak beraturan (acak).

Setelah mengerjakan lembar tugas dari guru hasil yang diperoleh siswa sudah cuku baik. Cara mengajar guru sudah sesuai dengan langkah-langkah mengajar dengan menggunakan Strategi Pre-Write, Organize, Write, Edit, Revise dan Share (POWERS) dimana guru memperlihatkan gambar terlebih dahulu dengan memberikan penjelasan tentang gambar yang tertera. Namun, yang seharusnya guru membagai kelas menjadi beberapa kelompok tetapi guru tidak melakukan hal tesebut. Selanjutnya guru memberikan satu contoh 
kalimat yang berhubungan dengan gambar yang ditunjukkan kepada siswa. Saat siswa tengah berdiskusi pada teman sebangkunya untuk membuat satu kalimat sederhana guru memberikan motivasi agar siswa lebih semangat. Salah satu dari siswa membacakan kalimat yang telah ditulis oleh mereka. Setelah itu guru memberikan soal yang berhubungan dengan materi, pada kali ini materi yang digunakan adalah numbers guru memberikan 2 jenis soal yang berbeda, siswa dilatih untuk menyusun kata yang hurufnya acak menjadi satu kosakata yang baik dan benar, dan soal selanjutnya adalah dengan melengkapi huruf yang rumpang sehingga kosa kata tersebut menjaadi lengkap. Setelah selesaai mengerjakan soal-soal tersebut, maka guru meminta siswa untuk menukar hasil kerjanya pada teman sebangkunya untuk dikoreksi secara bersamaan, guru melakukan evaluasi pada tahap ini. Setelah mengoreksi secara bersaamaan maka guru meminta siswa untuk mengumpulkan hasil kerjanya ke meja guru. Berikut merupakan langkah-langkah mengajar yang dilakukan oleh guru dengan menggunakan strategi Pre-Write, Organize, Write, Edit, Revise dan Share (POWERS) dalam pelajaran Bahasa Inggris dengan materi numbers pada siswa kelas dua SDIT Baiturrachman Kunciran Tangerang.

\section{KESIMPULAN}

Hasil penelitian ini menyimpulkan beberapa hal : (1) Strategi Pre-Write, Organize, Write, Edit, Revise dan Share (POWERS) cocok digunakan dalam meningkatkan kemampuan menulis siswa; (2) Strategi Pre-Write, Organize, Write, Edit, Revise dan Share (POWERS) tergolong efektif dan efisien daalam proses belajar mengajar; (3) Guru di SDIT Baiturrachman sudah dapat menerapkan strategi POWERS dengan baik meskipun masih ada beberapa langkah-langkah pembelajaran yang terlewat; (4) tingkat keberhasilan siswa dalam kemampuan menulis dengan menggunakan strategi Pre-Write, Organize, Write, Edit, Revise dan Share (POWERS) meningkat.

Berdasarkan hasil tersebut maka dapat disimpulkan bahwa strategi Pre-Write, Organize, Write, Edit, Revise dan Share (POWERS) dapat digunakan dan sangat cocok untuk meningkatkan kemampuan menulis Bahasa Inggris siswa sekolah dasar dan juga guru di SDIT Baiturrachman sudah berkompeten dalam mengajar dengan menggunakan strategi Pre-Write, Organize, Write, Edit, Revise dan Share (POWERS) karena dari hasil belajar yang 
kami teliti kemampuan menulis siswa meningkat dengan menggunakan strategi belajar tersebut.

\section{DAFTAR PUSTAKA}

Cohen, L. (2007). Research Methods in Education. In Research Methods in Education. https://doi.org/10.4324/9780203029053

Creswell, J. W. (2014). Research Design: Qualitative, Quantitative, and Mixed Method Approaches Creswell 4th Edition (4th ed.). Sage Publication.

Ratminingsih, N. M. (2019). Metode dan Strategi Pembelajaran Bahasa Inggris. In Raja Grafindo. https://doi.org/10.1017/CBO9781107415324.004

Samsudin, A. (IKIP Si. (2012). Peningkatan Kemampuan Menulis Eksposisi Berita Dan Menulis Eksposisi Ilustrasi Siswa Kelas V Melalui Model Pembelajaran Kooperatif Terpadu Membaca Dan Menulis. Penelitian Pendidikan UPI, 13(2), 1-11.

Sobari, T. (2012). Penerapan Metode Mengikat Makna dalam Pembelajaran Menulis Cerpen pada Mahasiswa IKIP Siliwangi Bandung. Sematik, 1(1), 17-38. https://doi.org/10.22460/semantik.vXiX.XXX

Yuliana, W. (2015). Teaching Writing by Combining POWER (Plan, Organize, Write, Edit, Revise) and T-Chart Strategy. Jurnal Ilmiah Mahasiswa SKTIP PGRI Sumatera Barat, 16(2), 39-55. https://doi.org/10.1377/hlthaff.2013.0625. 